\title{
Synthesis and crystal structure of a wheel-shaped supramolecular coordination complex
}

\author{
DEEPAK GUPTA, PALANISAMY RAJAKANNU, BHASKARAN SHANKAR, \\ FIRASAT HUSSAIN and MALAICHAMY SATHIYENDIRAN* \\ Department of Chemistry, University of Delhi, Delhi 110 007, India \\ e-mail: mvdiran@yahoo.com; msathi@ chemistry.du.ac.in
}

MS received 21 March 2014; accepted 8 April 2014

\begin{abstract}
Supramolecular coordination complex (SCC) possessing spatially arranged three anthraquinone dimers in a slipped-cofacial orientation was achieved by the treatment of $\operatorname{Re}_{2}(\mathrm{CO})_{10}, 2$ hydroxymethylanthraquinone and tritopic $\mathrm{N}$-donor via fac-Re(CO)$)_{3}$-directed one pot approach. The off-set $\pi$-stacking and $\mathrm{C} \equiv \mathrm{O} \cdots \mathrm{H}$ bonding interactions stabilize the ring structure.
\end{abstract}

Keywords. Rhenium; molecular ring; anthraquinone; non-covalent interactions; supramolecules; $\mathrm{X}$-ray structure.

\section{Introduction}

The metal-directed self-assembly methods and crystal $\mathrm{X}$-ray crystallography have been collectively providing supramolecular coordination complexes from aesthetically pleasing small to unimaginably big molecular architectures. ${ }^{1}$ The crystallographic analysis has become the most powerful analytical technique for the elucidation of the structure of the final product. The details of the structural parameters and the non-covalent interactions existing in the supramolecular coordination complexes (SCCs) provide motivation to create interesting and potential new molecules as well as mimics of naturally existing molecules.

A variety of metal-directed synthetic methods have been applied to design and synthesize distorted cycles and platonic solid shaped metallacycles e.g., rectangles, prisms and octahedron; modulating the size and properties of the final structure by changing either the organic building unit or metal cores. ${ }^{2}$ No attention has been paid to achieve wheel-shaped structures possessing spatially arranged $\pi$-dimers in a cyclic manner. However, owing to the poor-directionality of the $\pi-\pi$ interactions, the construction of non-covalently bound $\pi$-stacked dimers is challenging. ${ }^{3}$ Moreover, a cyclic arrangement of close lying, non-covalently linked chromophores is an important feature of the photosynthetic antenna and reaction centre proteins where a slippedcofacial orientation (SCO) of bacteriochlorophyll-a

\footnotetext{
*For correspondence
}

dimers in the light harvesting complexes (LHCs) plays a crucial role in photosynthetic bacteria. ${ }^{3}$ Keeping these under consideration, efforts are still being expanded on the design and synthesis of macrocyclic ring-like functional assemblies possessing non-covalently linked $\pi$-stacked dimers of porphyrin or other chromophores using metal-directed strategy. In this paper we report a one-step synthesis and crystal structure of a wheelshaped supramolecule possessing cyclic arrangement of slipped-cofacial dimers of anthraquinone units.

\section{Experimental}

\subsection{General experimental methods}

$\mathrm{Re}_{2}(\mathrm{CO})_{10}$, 2-hydroxymethylanthraquinone (H-mAq) and 2,4,6-tris(4'-pyridyl)-1,3,5-triazine (tpt) were purchased from commercial sources and used as received. Toluene was purified by conventional procedures and distilled prior to use. Infrared spectra were recorded on a Perkin-Elmer FT-IR Spectrometer. ${ }^{1} \mathrm{H}$ NMR spectra for $\mathbf{1}$ and the bulk product were recorded on a Bruker AMX-400 FT-NMR spectrometer. ICPMS was recorded on a Perkin-Elmer ICP Mass Spectrometer. Xray data for complex 1 was collected using an OXFORD XCALIBUR-S CCD single crystal X-ray diffractometer. The structure was solved and refined by full-matrix least-squares techniques on $\mathrm{F}^{2}$ using the SHELX-97 program. ${ }^{10}$ The absorption corrections were done by multiscan (SHELXTL program package), and all the data was corrected for Lorentz, polarization effects. 


\subsection{Synthesis of hexanuclear complex 1}

A mixture of $\operatorname{Re}_{2}(\mathrm{CO})_{10}$ (98.4 mg, $\left.0.15 \mathrm{~mol}\right)$, tpt (32 mg, $0.10 \mathrm{mmol})$, and $\mathrm{H}-\mathrm{mAq}(71.5 \mathrm{mg}, 0.30 \mathrm{mmol})$ in toluene $(15 \mathrm{~mL})$ was placed in a Teflon inliner which was placed in a stainless steel autoclave. The autoclave was placed in an oven maintained at $150^{\circ} \mathrm{C}$ for $25 \mathrm{~h}$ and then cooled to room temperature. Good quality single crystals of $\mathbf{1}$ were separated from the resulting product and washed with pet-ether. Yield: $68.1 \mathrm{mg}$. FTIR $\left(\mathrm{KBr} / \mathrm{cm}^{-1}\right): 2023(\mathrm{C} \equiv \mathrm{O}), 2018(\mathrm{C} \equiv \mathrm{O})$, $1809(\mathrm{C} \equiv \mathrm{O}), 1674(\mathrm{C}=\mathrm{O}) .{ }^{1} \mathrm{HNMR}\left(d_{6}\right.$-DMSO): $\delta$ $8.95\left(12 \mathrm{H}, \mathrm{d},{ }^{3} J_{\mathrm{H}, \mathrm{H}}=6 \mathrm{~Hz}, \mathrm{H}^{\mathrm{a}}, \mathrm{tpt}\right), 8.64(12 \mathrm{H}$, $\left.\mathrm{d},{ }^{3} J_{\mathrm{H}, \mathrm{H}}=6 \mathrm{~Hz}, \mathrm{H}^{\mathrm{b}}, \mathrm{tpt}\right), 8.22-8.19\left(12 \mathrm{H}, \mathrm{m}, \mathrm{H}^{8,5}\right.$, mAq), 8.18 (6 H, s, $\left.\mathrm{H}^{1},-\mathrm{mAq}\right), 7.94-7.91(12 \mathrm{H}, \mathrm{m}$, $\left.\mathrm{H}^{7,6},-\mathrm{mAq}\right), 7.85\left(6 \mathrm{H}, \mathrm{d}, \mathrm{H}^{3},-\mathrm{mAq}\right), 5.6(6 \mathrm{H}, \mathrm{t},-\mathrm{OH}$, $\mathrm{mAq}), 4.7\left(12 \mathrm{H}, \mathrm{d},{ }^{2} \mathrm{~J}_{\mathrm{H}, \mathrm{H}}=6 \mathrm{~Hz},-\mathrm{CH}_{2^{-}},-\mathrm{mAq}\right)$.

\subsection{Crystal diffraction data}

$\mathrm{C}_{144} \mathrm{H}_{78} \mathrm{~N}_{12} \mathrm{O}_{37} \mathrm{Re}_{6}, M=3685.45$, hexagonal, $a=$ 24.1039(6), $b=24.1039(6), c=13.1545(3) \AA, \alpha=90$, $\beta=90, \gamma=120^{\circ}, V=6618.8(3) \AA^{3}, T=183(2) \mathrm{K}$, space group $\mathrm{P}_{3} 2_{2}, Z=2, \mu(\mathrm{Mo}-\mathrm{K} \alpha)=5.552 \mathrm{~mm}^{-1}$, 36038 reflections measured, 4214 unique $\left(R_{\text {int }}=\right.$ $0.0926)$ which were used in all calculations. GOF on $F^{2}: 0.650 . \mathrm{R}^{\mathrm{a}}[\mathrm{I}>2 \sigma(\mathrm{I})]: 0.0364 . R_{\mathrm{w}}^{\mathrm{b}}$ (all data): 0.0837 . The final $w R\left(F_{2}\right)$ was 0.1057 (all data).

\section{Results and discussion}

\subsection{Characterization}

A combination of $\operatorname{Re}_{2}(\mathrm{CO})_{10}$, 2-hydroxymethyl-9,10anthraquinone (H-mAq) and 2,4,6-tris(4'-pyridyl)1,3,5-triazine (tpt) in toluene under solvothermal conditions leads to a mixture of products as brown crystals and light-brown powder (scheme 1 and eq. 1). Few bigger crystals out of the bulk product were handpicked under a microscope and used for structural analysis. The crystalline product $\left[\left(\operatorname{Re}(\mathrm{CO})_{3}\right)_{6}(\mathrm{mAq})_{6}(\mathrm{tpt})_{2}\right]$ (1) and powder $\left[\left(\operatorname{Re}(\mathrm{CO})_{3}\right)_{6}(\mathrm{OH})_{6}(\mathrm{tpt})_{2}\right](2)$ are airand moisture-stable and poorly soluble in most of the organic solvents. The FT-IR spectrum of $\mathbf{1}$ exhibits strong bands at 2023, 2018, and $1809 \mathrm{~cm}^{-1}$,<smiles>CC(=O)OC(C)=O</smiles><smiles>c1cc(-c2nc(-c3ccncc3)nc(-c3ccncc3)n2)ccn1</smiles>

(tpt)

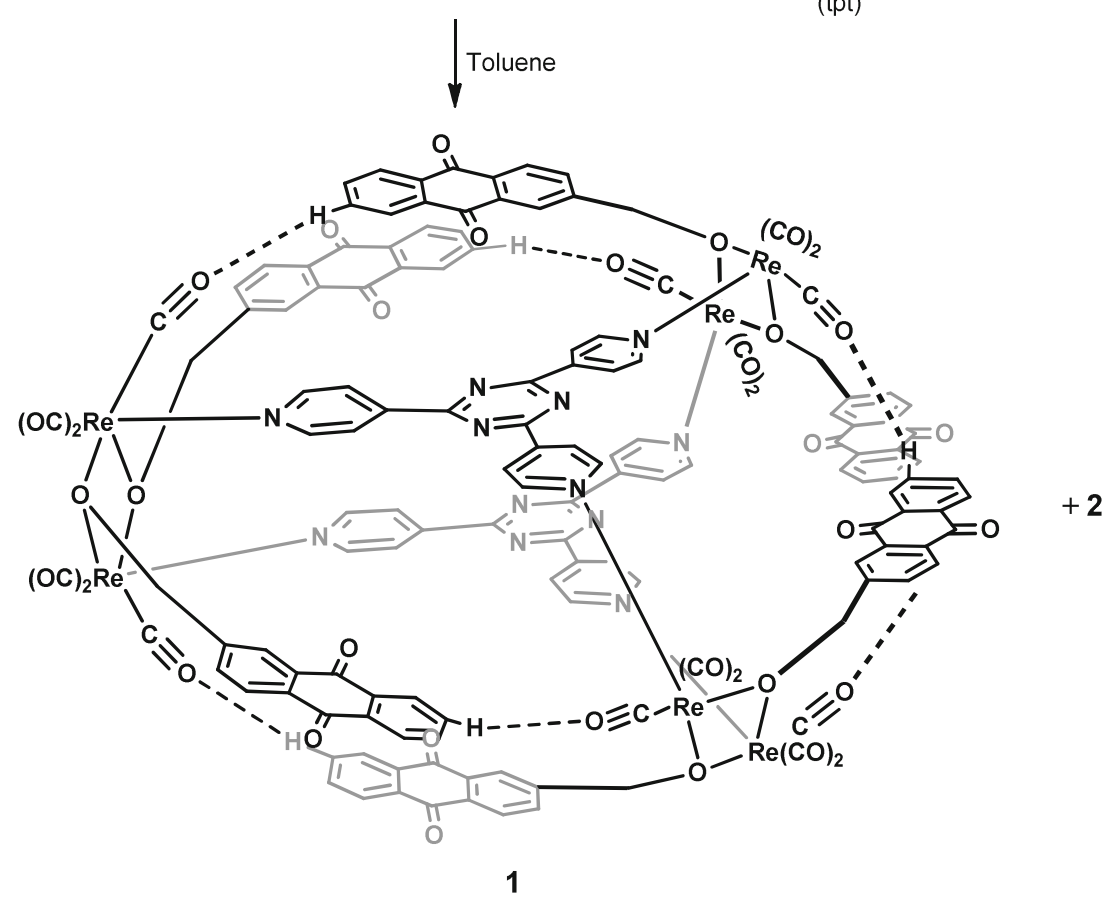

Scheme 1. Multicomponent assembly of metallomacroring $\mathbf{1 .}$ 
characteristic of $f a c-\operatorname{Re}(\mathrm{CO})_{3}$ moiety in an asymmetric environment. ${ }^{4}$ The absorption band at $1674 \mathrm{~cm}^{-1}$ is attributed to the stretching vibrations of $\mathrm{C}=\mathrm{O}$ bond of the anthraquinone fragments (figure S2). ${ }^{5}$ The ${ }^{1} \mathrm{HNMR}$ spectrum of $\mathbf{1}$ dissolved in $d_{6}$-DMSO by heating shows a pair of doublets $(8.95,8.64 \mathrm{ppm})$ for the pyridyl protons of the tpt units. No significant chemical shifts were observed for the protons of anthraquinone unit in $\mathbf{1}$ as compared to anthraquinone protons of the free ligand which indicated towards the poor stability of complex $\mathbf{1}$ in solution (figure S3 in $\left.\mathrm{ESI}^{\dagger}\right)$.

$$
6 \operatorname{Re}_{2}(\mathrm{CO})_{10}+6 \mathrm{H}-\mathrm{mAq}+4 \mathrm{tpt} \longrightarrow\left[\left(\operatorname{Re}(\mathrm{CO})_{3}\right)_{6}(\mathrm{mAq})_{6}(\mathrm{tpt})_{2}\right]+\left[\left(\operatorname{Re}(\mathrm{CO})_{3}\right)_{6}(\mathrm{OH})_{6}(\mathrm{tpt})_{2}\right]+24 \mathrm{CO}
$$

However, the ${ }^{1}$ HNMR spectrum of the powder sample shows two types of resonance patterns; one of the patterns match exactly with that of the crystalline product (1), while the other indicates the formation of a hydroxyl-bridged trigonal prism (2) (figure S3). The observation of the molecular ion peak at $2371.87 \mathrm{~m} / \mathrm{Z}$ for (2) in the ICPMS spectrum confirmed the presence of $\mathbf{2}$ (figure S4). Several attempts to procure pure 1 by varying the concentration of starting materials and reaction conditions were fruitless. The complete separation of $\mathbf{1}$ from the bulk was extremely difficult due to the poor solubility and tininess of the crystals. Based on the integration ratios of the ${ }^{1} \mathrm{HNMR}$ resonances, the yield of complex $\mathbf{1}$ was estimated to be above $30 \%$. Therefore, it can be proposed that the bulk product consists of a mixture of $\mathbf{1}$ and $\mathbf{2}$.

\section{$3.2 X$-ray crystal structure}

Compound 1 crystallizes in a chiral space group $\mathrm{PC}_{3} 2_{2}$ and adopts a spoked-wheel structure (figure 1). The ring in $\mathbf{1}$ is composed of alternatively arranged three rigid modules of anthraquinone dimers $(\mathrm{mAq})_{2}$ and three $\left((\mathrm{CO})_{3} \operatorname{Re}-\left(\mu_{2}-\mathrm{O}\right)_{2}-\operatorname{Re}(\mathrm{CO})_{3}\right)$ units having a diameter of about $2.2 \mathrm{~nm}$ including the van der Waals radii. The two tpt units act as spokes to support the ring structure. Several intramolecular non-covalent interactions such as $\mathrm{C}-\mathrm{H} \cdots \mathrm{O} \equiv \mathrm{C}$ and $\pi-\pi$ stacking stabilize the ring framework. The slipped-cofacial headto-head orientation, planarity and tilted angle favours the strong electrostatic self-complimentary $\pi-\pi$ interactions of electron rich arene portions to electron poor quinone portions of $\mathrm{Aq}$ units in $(\mathrm{mAq})_{2}$ dimer units in 1 (figure 1). The distance between the two anthraquinone moieties in a anthraquinone dimer is in the range of 3.6 to $3.8 \AA$ (figure 2). Complex 1 has three anthraquinone dimer sets and the distance between the two mAq duplexes is $c a$. $7.27 \AA$. The hydrogen atom of the sixth carbon of anthraquinone unit bridges to a nearby carbonyl unit $(\mathrm{C}-\mathrm{H} \cdots \mathrm{O} \equiv \mathrm{C}$ $\left(\mathrm{D}=3.11 \AA, \mathrm{d}=2.32 \AA, \theta=143^{\circ}\right)$ ) in a concerted fashion to complete the ring structure (figure 2). ${ }^{6}$ Examples of metal-based trigonal-prisms were reported
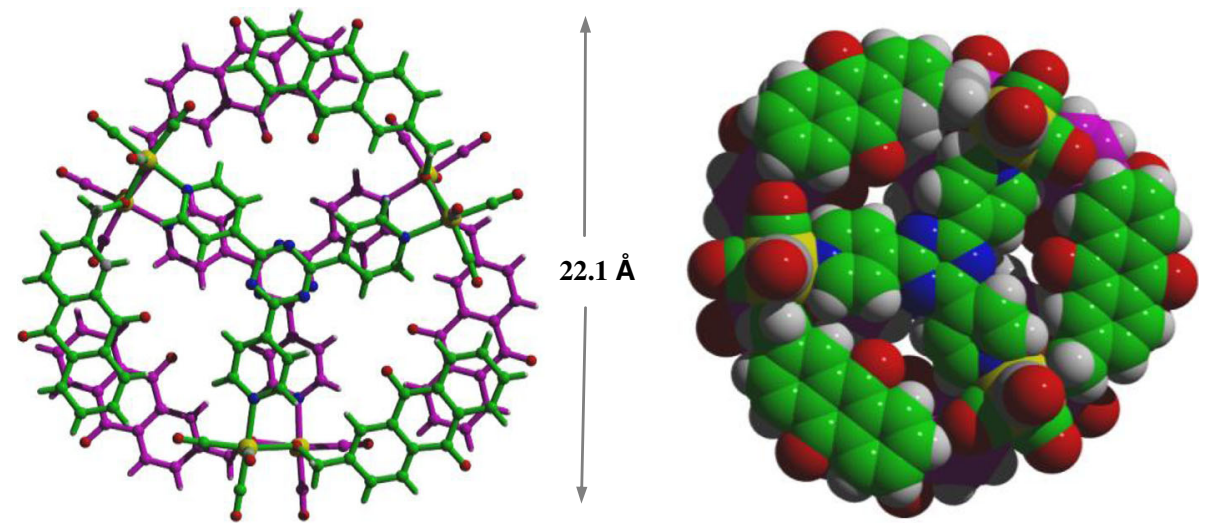

Figure 1. Structure of $\mathbf{1}$ (ball and stick and space-filling representations, Green = rose $=\mathrm{C}$, white $=\mathrm{H}$, blue $=\mathrm{N}$, red $=\mathrm{O}$, yellow $=\mathrm{Re}$ ). 

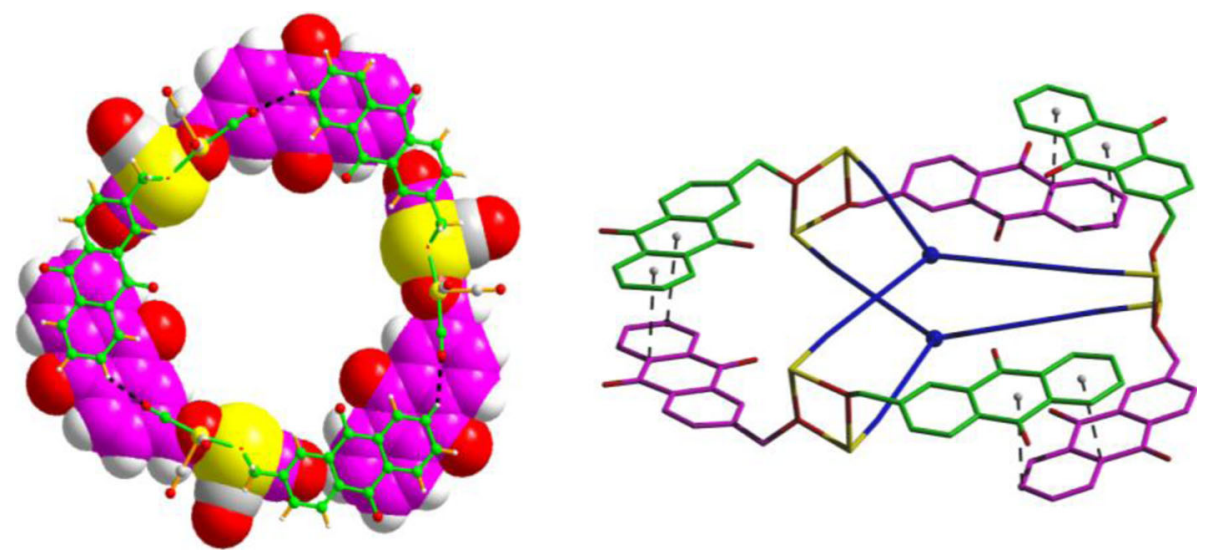

Figure 2. Left: space-filling and ball and stick view of $\mathbf{1}$ showing intramolecular H-bonds (two tpt units are omitted). Right: stick view of $\mathbf{1}$ showing dimeric unit (two tpt units are shown as blue sticks, $\mathrm{H}$ atoms and carbonyl groups are omitted for clarity).

previously by us and others. ${ }^{4}$ To the best of our knowledge, this is the first report on SCC with more than one slipped-cofacially arranged organic dimers in a cyclic manner. ${ }^{1,4}$

Interestingly, the tpt units are found to be twisted in the trigonal prismatic framework of SCC 1 . The cofacial pyridyl subunits are out of the plane of the triazine rings by an angle of $21.5^{\circ}$ and are not perfectly eclipsed; inducing chirality to 1 (triazines, dihedral angle $=0, \mathrm{~d}$ (centroid $\cdots$ centroid distance $)=3.4 \AA$; pyridines, tilted angle $=21.5^{\circ}$, dihedral angle $=2.3^{\circ}, \mathrm{d}=3.4-3.5 \AA$ ) (figure 3). A variety of tpt based metalloprisms having the eclipsed pyridyl units are known to be achiral. ${ }^{4}$ The degree of deviation from the trigonal prismatic geometry is measured by the Bailar Twist Angles which is $18.29^{\circ}$ for all the three pyridyl dimers. ${ }^{7}$ A very few chiral self-assembled metalloprisms are known in the literature. ${ }^{8}$

Another feature of complex $\mathbf{1}$ is its packing arrangement. It extends as 2D hexagonal layered structure along the $a b$ direction, stabilized by intermolecular $\mathrm{C}-\mathrm{H} \cdots \mathrm{O}$ interactions between anthraquinone units $(\mathrm{C}-\mathrm{H} \cdots \mathrm{O}=\mathrm{C}, \mathrm{D}=3.37 \AA, \mathrm{d}=2.46 \AA, \theta=$ $\left.165.7^{\circ}\right)$. Each anthraquinone in the ring interacts with anthraquinone units of the two neighbouring rings; hence, overall each macrocyclic ring interacts with six others (figure 4). A similar type of self-assembled $\mathrm{H}$-bonded trimer of anthraquinone molecules was observed on a $\mathrm{Cu}(111)$ surface. ${ }^{9}$ In addition, the sheets are stacked in an $A B A B$ layered pattern along the $c$-axis, resulting in 3D supramolecular network through extensive intermolecular $\pi \cdots \pi$ stacking interactions.
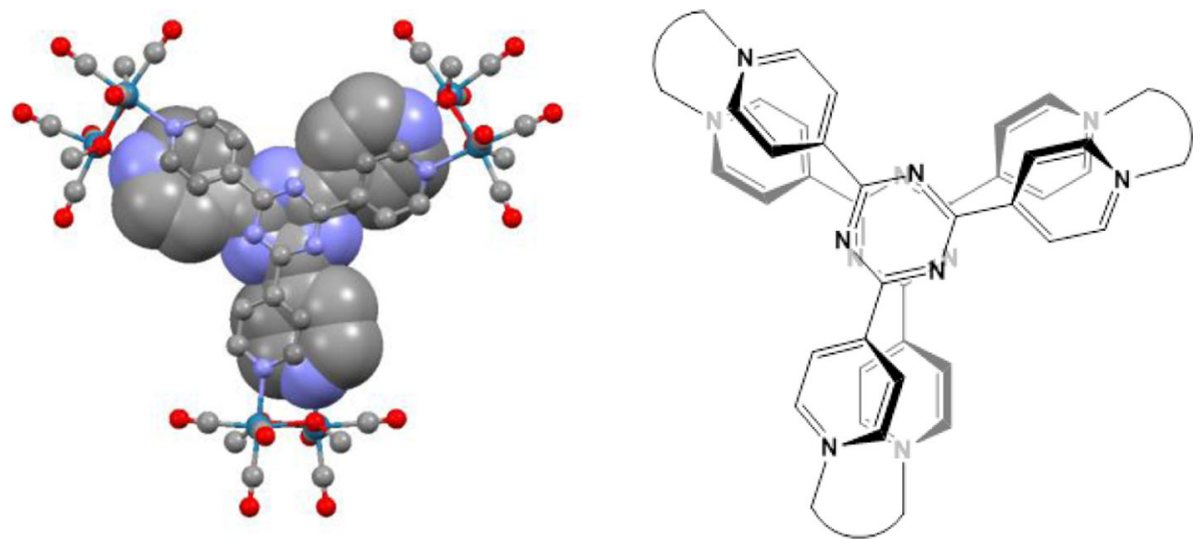

Figure 3. The Bailar Twist between the two tpt frameworks in the macrocycle $\mathbf{1}$. All the three staggered pyridyl units show equal twist of $18.29^{\circ}$. The Aq dimers and hydrogens have been removed for clarity. 



Figure 4. Top: space-filling and ball and stick view of portion of layers of molecules of 1. Down: one layer containing six SCCs showing H-bonding interactions.

\section{Conclusion}

These findings proffer a one-step design strategy to achieve nanocyclic ring structure consisting of organic chromophores positioned as slipped-cofacial dimers. We believe this metal-directed building principle would provide a new direction to assemble wheel-shaped supramolecules with photoactive units. Current research in our laboratory is directed to replace anthraquinone unit by porphyrin and other light harvesting units in similar systems as complex $\mathbf{1}$.

\section{Supplementary Information}

The electronic supplementary information can be seen at www.ias.ac.in/chemsci.

\section{Acknowledgements}

We thank Prof. R. Murugavel, IIT-Bombay for scientific support and the University Grants Commission (UGC)
(F. No. 41-218/2012 (SR)), India for financial support. DG and BS thank the Council of Scientific and Industrial Research (CSIR) for Senior Research Fellowship. We are grateful to Perkin-Elmer for ESI-Mass analysis.

\section{References}

1. (a) Lehn J M 1995 In Supramolecular Chemistry, Concepts and Perspectives (Weinheim: VCH); (b) Janiak C 2000 J. Chem. Soc., Dalton Trans. 3885; (c) Chakrabarty R, Mukherjee P S and Stang P J 2011 Chem. Rev. 111 6810; (d) Fujita M, Umemoto K, Yoshizawa M, Fujita N, Kusukawa T and Biradha K 2001 Chem. Commun. 509; (e) Gianneschi N C, Masar III M S and Mirkin C A 2005 Acc. Chem. Res. 38 825; (f) Han Y F, Jia W G and Jin G X 2009 Chem. Soc. Rev. 38 3419; (g) Nohra B, Graule S, Lescop C and Reau R 2006 J. Am. Chem. Soc. 1283520

2. (a) Amouri H, Desmarets C and Moussa J 2012 Chem. Rev. 112 2015; (b) Liao R T, Yang W C, Thanasekaran P, Tsai C C, Sathiyendiran M, Liu Y H, Rajendran T, Lin H M, Tseng T W and Lu K L 2008 Chem. Commun. 3175; (c) Shankar B, Elumalai P, Hussain F 
and Sathiyendiran M 2013 J. Organomet. Chem. 732 130; (d) Pardo E, Faus J, Lloret F, Munoz M C, Cano J, Ottenwaelder X, Journaux Y, Carrasco R, Blay G, Fernandez I and Ruiz-García R $2003 \mathrm{~J}$. Am. Chem. Soc. 125 10770; (e) Shankar B, Sahu S, Deibel, N, Schweinfurth D, Sarkar B, Elumalai P, Gupta D, Hussain F, Krishnamoorthy G and Sathiyendiran M 2014 Inorg. Chem. 53 922; (f) Shankar B, Elumalai P, Shanmugam R, Singh V, Masram D T and Sathiyendiran M 2013 Inorg. Chem. 52 10217; (g) Rajakannu P, Elumalai P, Shankar B, Hussain F and Sathiyendiran M 2013 Dalton Trans. 42 11359; (h) Gupta D, Shankar B, Elumalai P, Shanmugam R, Mobin S M, Weisser F, Sarkar B and Sathiyendiran M 2014 J. Organomet. Chem. 754 59; (i) Shankar B, Rajakannu P, Kumar S, Gupta D, Kannan T and Sathiyendiran M 2011 Inorg. Chem. Commun. 14 374; (j) Rajakannu P, Elumalai P, Hussain F andSathiyendiran M 2013 J. Organomet. Chem. 725 1; (k) Shankar B, Elumalai P, Shanmugam R and Sathiyendiran M 2014 J. Organomet. Chem. 749 224; (1) Rajakannu P, Shankar B, Yadav A, Shanmugam R, Gupta D, Hussain F, Chang C H, Sathiyendiran M and Lu K L 2011 Organometallics 303168

3. (a) Yang J, Yoon M C, Yoo H, Kim P and Kim D 2012 Chem. Soc. Rev. 41 4808; (b) Ahrens M J, Sinks L E, Rybtchinski B, Liu W, Jones B A, Giaimo J M, Gusev A V, Goshe A J, Tiede D M and Wasielewski M R 2004 J. Am. Chem. Soc. 126 8284; (c) Satake A and Kobuke Y 2007 Org. Biomol. Chem. 5 1679; (d) McDermott G, Prince S M, Freer A A, Hawthornthwaite-Lawless A M, Papiz M Z, Cogdell R J and Isaacs N W 1995 Nature 374 517; (e) Bhosale S, Sisson A L, Talukdar P, Fürstenberg
A, Banerji N, Vauthey E, Bollot G, Mareda J, Röger C, Würthner F, Sakai N and Matile S 2006 Science 84 313

4. (a) Benkstein K D and Hupp J T 2000 Mol. Cryst. Liq. Cryst. 342 151; (b) Sun S S and Lees A J 2001 Chem. Commun. 103; (c) Manimaran B, Rajendran T, Lu Y L, Lee G H, Peng S M and Lu K L 2001 Eur. J. Inorg. Chem. 633; (d) Gupta D, Rajakannu P, Shankar B, Shanmugam R, Hussain F, Sarkar B and Sathiyendiran M 2011 Dalton Trans. 40 5433; (e) Wu T, Weng L H and Jin G X 2012 Chem. Commun. 48 4435; (f) Mirtschin S, Slabon-Turski A, Scopelliti R, Velders A H and Severin K 2010 J. Am. Chem. Soc. 132 14004; (g) Therrien B 2009 Eur. J. Inorg. Chem. 2445; (h) Wu J Y, Chang C H, Thanasekaran P, Tsai C C, Tseng T W, Lee G H, Peng S M and Lu K L 2008 Dalton Trans. 6110

5. Song Z, Zhan H and Zhou Y 2009 Chem. Commun. 448

6. (a) Desiraju G R 2005 Chem. Commun. 2995; (b) Rajadurai C, Fuhr O, Enkelmann V and Baumgarten M 2006 J. Phys. Org. Chem. 19257

7. Bailar Jr. J C 1958 J. Inorg. Nucl. Chem. 8165

8. (a) Govindaswamy P, Linder D, Lacour J, Süss-Fink G and Therrien B 2006 Chem. Commun. 4691; (b) Caskey D C, Yamamoto T, Addicott C, Shoemaker R K, Vacek J, Hawkridge A M, Muddiman D C, Kottas G S, Michl J and Stang P J 2008 J. Am. Chem. Soc. 1307620

9. (a) Pawin G, Solanki U, Kwon K Y, Wong K L, Lin X, Jiao T and Bartels L 2007 J. Am. Chem. Soc. 129 12056; (b) Pawin G, Wong K L, Kwon K Y and Bartels L 2006 Science 313961

10. (a) CrysAlis Pro software system, Version 171.32; Oxford Diffraction Ltd., Oxford, U.K., 2007; (b) Sheldrick G M 2008 Acta. Crystallogr. A 64112 